

Digitized by the Internet Archive in 2011 with funding from University of Toronto 



CONTRIBUTIONS OF THE

ROYAL ONTARIO MUSEUM OF ZOOLOGY .

No. 32: FLUCTUATIONS IN ABUNDANGE OF THE LAKE ERIE CISCO (Leucichthys artedi) POPULATION

By W. B. ScotT 

FLUCTUATIONS IN ABUNDANCE OF THE LAKE ERIE CISCO (Leucichthys artedi) POPULATION 



\section{TABLE OF CONTENTS}

Introduction

Acknowledgments

Description of lake Erie . . . . . . . . . 8

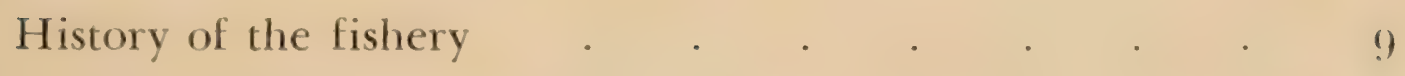

Types of gear used in lake Erie . . . . . . . 13

Chief Canadian gill netting localities . . . 14

History and statistics of production . . . . . 15

Canadian production by counties . . . . 22

Comparison of Canadian and American production . 25

Canadian cisco production of lake Erie compared with that of the remaining Great Lakes . . $\quad 27$

Age composition of samples . . . . . . 29)

Years of peak abundance . . . . . . . . 30

Importance of size of spawning stock . $\quad . \quad 3 \quad$. $\quad 32$

Factors responsible for dominant year-classes • • . 32

Factors influencing hatching and survival . . . 33

Plankton abundance . . . . . . . . . 34

Predation . . . . . . . . . . 34

Disease . . . . . . . . . . . 35

Fecundity of lake Erie ciscoes . . . . . . 35

Summary . . . . . . . . . . . . $3^{8}$

Appendix . . . . . . . . . . 40 


\section{LIST OF TABLES}

Table

I Canadian catch of lake Erie ciscoes expressed as a percentage of the total cisco catch for Canadian waters of the Great Lakes during the period $1937-194^{6 .}$

II Annual Canadian production in hundreds of pounds of lake Erie ciscoes or lake herring, 1867 to 1946 .

III Average number of pounds of ciscoes per pound net taken at Rondeau, Ontario, in various years during the period 1899-1927 (from Van Oosten, 1930).

IV Percentage of total lake Erie Canadian cisco production by counties for the period 1937 to 1946 , inclusive.

V Catch of lake Erie ciscoes, 1913 to 1946.

VI Year-class composition of yearly samples of lake Erie ciscoes taken from two regions of the lake.

VII Summary of statements and observations regarding size of individuals and relative abundance of ciscoes in lake Erie during the period 1891-1947.

VIII Average fecundity, length and weight of 104 Irondequoit Bay ciscoes (from Stone, 1937).

IX Egg counts for lake Erie ciscoes at ages II and III. 


\section{LIST OF FIGURES}

Figure

Title

Page

1 The lake Erie cisco (Leucichthys artedi).

$2 \quad$ Map of lake Erie.

10

3 Annual Canadian production of lake Erie ciscoes, 1880 to $194^{6}$.

4 Canadian cisco production of lake Erie by counties.

5) Comparison of Canadian, American and total catch of lake Erie ciscoes for the period 1913 to 1945. (Canadian production includes 1946.

6 Canadian production of lake herring of lake Erie compared with that of the remaining Great Lakes. 


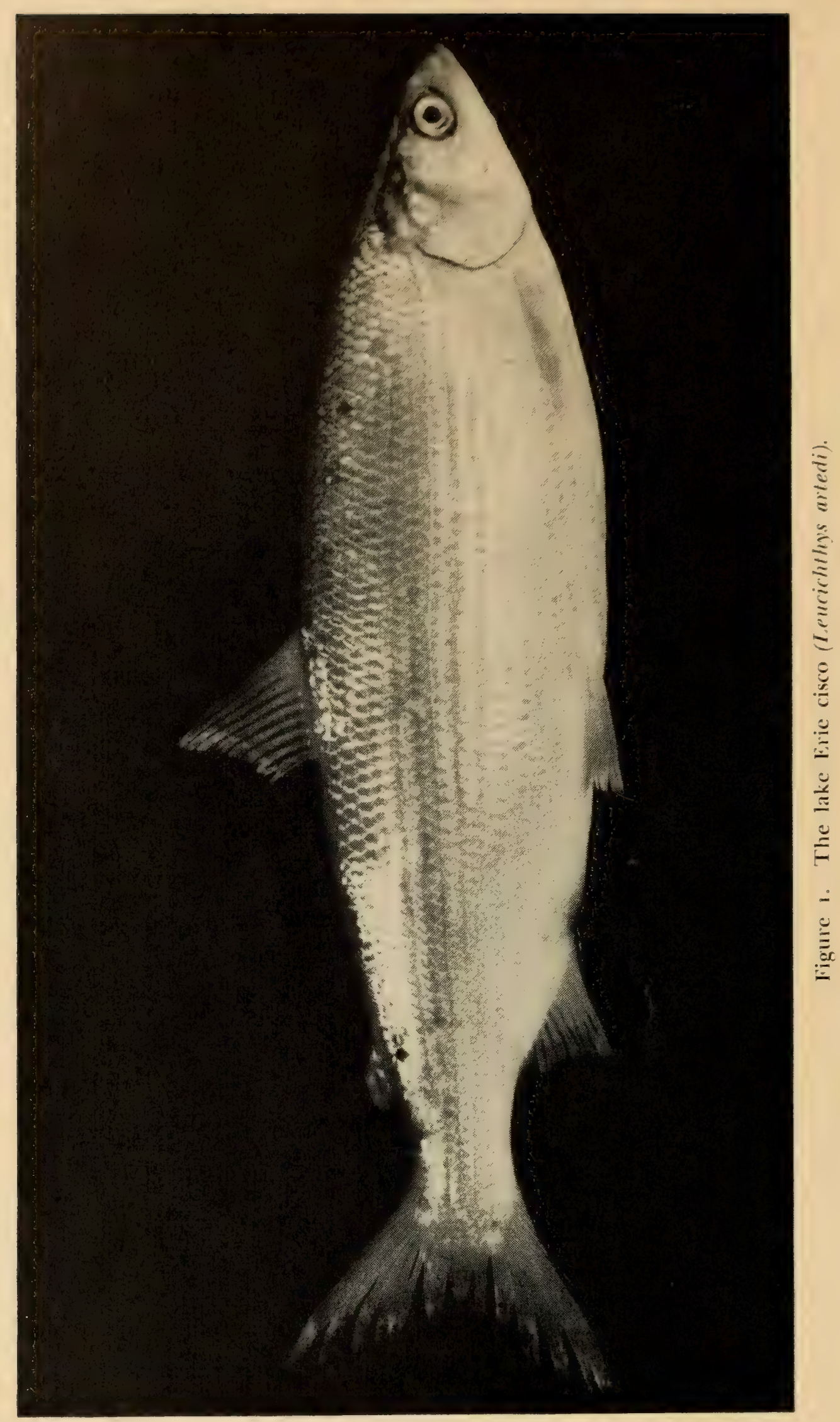




\title{
FLUCTUATIONS IN ABUNDANCE OF THE LAKE ERIE CISCO (Leucichthys artedi) POPULATION
}

\author{
by W. B. Scott
}

\section{INTRODUGTION}

The problems of fluctuating animal populations have attracted considerable attention in recent years. The fact that these more or less regular fluctuations appear to be restricted to temperate and arctic regions makes the problem of particular interest to zoologists of North America. Perhaps nowhere in the world are these periodic fluctuations more noticeable or more marked than in the northern portion of North America, especially Canada.

The populations of many Canadian birds and mammals have been shown to rise and fall in numbers with surprising regularity. Among the birds, the snowy owl (Nyctea scandiaca) and the ruffed grouse (Bonasa umbellus) are excellent examples of species whose populations have shown a periodic rise and fall in numbers. In the case of mammals, periodic fluctuations of population are exhibited by the red fox (Vulpes fulva), arctic fox (Alopex lagopus), Canada lynx (Lynx canadensis), the varying hare (Lepus americanus) and the lemming (Lemmus trimucronatus and Dicrostonyx hudsonius).

The same phenomenon has been shown to exist for the populations of some marine and freshwater organisms, to a lesser degree, however, than in the case of land animals. Burkenroad (1946) has demonstrated rather conclusively that the starfish (Asterias forbesi) population of the New England coastal waters reaches a peak of abundance approximately every fourteen years.

Probably the most marked example of a population exhibiting wide periodic fluctuations is afforded by the sockeye salmon (Oncorhynchus nerka) of the Fraser River. Further examples of fluctuating fish populations exist among such species as the pink salmon (Oncorhynchus gorbuscha) of the Pacific coast, and the Atlantic salmon (Salmo salar).

Dymond (1947) has noted that two types of population fluctuation may be recognized - the periodic and the non-periodic. All examples mentioned thus far are of the periodic type, but the non-periodic type of fluctuation is of equal importance. 
The smelt (Osmerus mordax), which was introduced into the (rreat Lakes, affords an excellent example of this latter type of fluctuation (Stevenson, 1944). From 1925 to 1941 the smelt population of lake Huron increased at an amazing rate. In $194^{2}$ the population suffered a drastic decline in numbers and huge quantities of dead smelts were cast up on shore or seen floating on the water.

The study of fluctuations in animal populations is of both economic and scientific importance. In all our efforts to intelligently manage our fisheries and wildlife resources we are concerned with the size of populations, either in attempts to increase the numbers of useful species or to decrease the numbers of destructive species.

Sound predictions of the approximate size of fish populations would be of inestimable value in planning for the handling of the expected crop.

Pearl (1937) has shown that the biological principles underlying population phenomena are fundamentally identical in man and other animals. Elton has repeatedly $(1924,1930,1942)$ emphasized the importance of periodic fluctuations in animal numbers in determining the course of evolution.

Few fisheries have shown more violent fluctuations than that of the lake Erie cisco. The appearance of an unusually large population in 1945 and 1946 , after a long period during which relatively low populations had existed, seemed to offer an opportunity to throw some light on this important phenomenon of fluctuations in animal numbers.

\section{ACKNOWLEDGMENTS}

The author is indebted to Professor J. R. Dymond for his advice and constructive criticism in the preparation of the manuscript.

The interest and cooperation of the W. F. Kolbe Company, Port Dover, Ontario, and the lake Erie fishermen, especially those of Port Dover, are sincerely appreciated.

Financial assistance was provided by the Research Division, Ontario Department of Lands and Forests, and through funds made available by the Research Council of Ontario.

\section{DESCRIPTION OF LAKE ERIE}

Lake Erie (figure 2) is one of the smallest of the Great Lakes, exceeding in size only lakes Ontario and St. Clair. It has an 
average width of about 45 miles and a length of about 250 miles. Its area is approximately 10,000 square miles. I ake riric is also one of the shallowest of the Great Lakes. exceeding in depth only lake St. Clair. The maximum depth of 35 fathoms is to be found eight to ten miles off the castern extremity of Long Point. The eastern portion of the lake is the deepest, these deeper waters being shared by Pennsylvania and New York States on the American side, and by the Province of (Ontario on the Canadian side. The shallower portion of the lake occurs from Long Point westward. From I ong Point to Point Pelec a maximum depth of about 14 fathoms occurs, while westward of Point Pelee the maximum depth is approximately seven fathoms.

The waters of the upper Great Lakes drain into lake Erie via lake St. Clair and the Detroit River and the lake in turn drains into lake Ontario via the Niagara River.

The entire north shore is bordered by the Province of Ontario, while the states of Michigan, Ohio, Pennsylvania and New York share the southern shore from west to east respectively.

\section{HISTORY OF THE FISHERY}

For more than half a century the cisco or lake herring has occupied an important place among the commercially valuable fishes of lake Erie. From 1887 to 19oo, the Canadian fishery remained reasonably stable but after 1900 the annual yield showed marked fluctuations. In the case of the American fishery, reports indicate that marked fluctuations occurred previous to 1900. Unfortunately, previous to 1913, American annual production figures are incomplete so that statistics of the total production for the early years of the fishery are not available. Since about 1900, however, the production of lake herring in Canadian and American waters has fluctuated violently. Indeed, so violent were these fluctuations that at times the fishery virtually ceased to exist.

In recent years, a phenomenal return of the lake herring has been witnessed, with production comparable to that of the early 1920's, after a long period, from 1925 to the early 1940's, during which time practically no commercial fishery existed.

Although the fishery does vary greatly from year to year, yet over the last ten years lake Erie has produced an average of $38 \%$ of the total poundage of all lake herring caught in the Canadian 


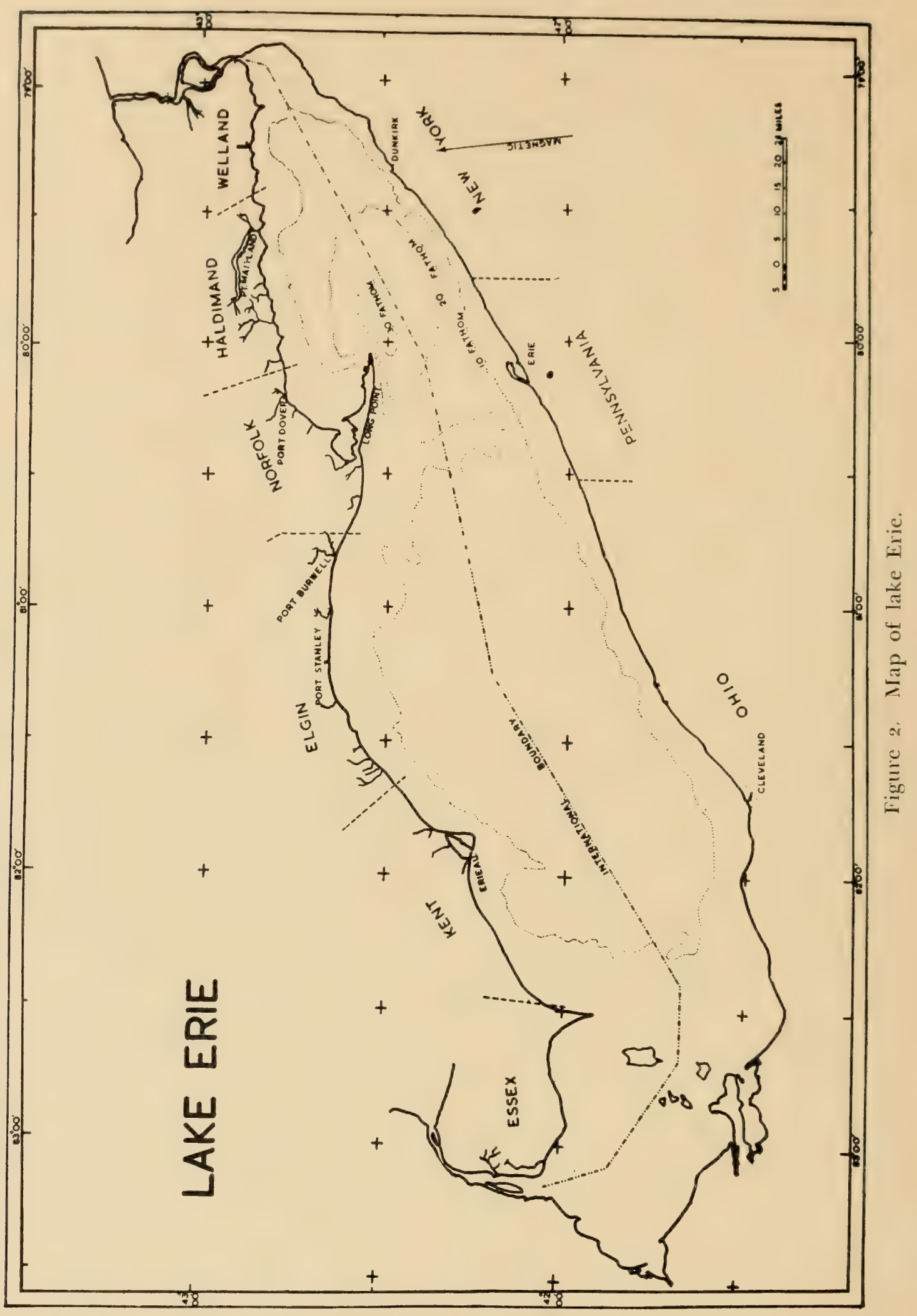


waters of the Great Lakes, varying from $2 \%$ in years of low abundance to over so", during years of peak abundance (tab)e 1 and figure 3 ).

\begin{tabular}{|c|c|c|c|}
\hline Year & $\begin{array}{c}\text { Production of } \\
\text { ciscoes from } \\
\text { Canadian waters } \\
\text { of the } \\
\text { Great Lakes, } \\
\text { in pounds }\end{array}$ & $\begin{array}{l}\text { Production of } \\
\text { ciscoes from } \\
\text { Canadian waters } \\
\text { of lake Erie, } \\
\text { in pounds }\end{array}$ & $\begin{array}{c}\text { Percentage } \\
\text { of tolal } \\
\text { for } \\
\text { Great Lakes } \\
\text { taken in } \\
\text { lake Erie }\end{array}$ \\
\hline $\begin{array}{l}1937 \\
1938 \\
1939 \\
1940 \\
1941 \\
1942 \\
1943 \\
1944 \\
1945 \\
1946 \\
\text { Total }\end{array}$ & $\begin{array}{r}4,984,916 \\
5,210,189 \\
5,670,631 \\
4,218,100 \\
4,253,985 \\
3,284,678 \\
2,745,284 \\
3,460,034 \\
9,121,670 \\
11,574,377 \\
54,523,864\end{array}$ & $\begin{array}{r}99,400 \\
1,374,500 \\
1,973,400 \\
585,499 \\
115,559 \\
64,789 \\
55,684 \\
335,598 \\
6,444,991 \\
9,524,975 \\
20,574,395\end{array}$ & $\begin{array}{r}2 \\
26 \\
35 \\
14 \\
3 \\
2 \\
2 \\
10 \\
71 \\
82 \\
38\end{array}$ \\
\hline
\end{tabular}

Table I.* Canadian catch of lake Erie ciscoes expressed as a percentage of the total cisco catch for the Canadian waters of the Great Lakes, during the period 1937-1946.

* Compiled from: Annual reports of the Ontario Department of Game and Fisheries; Annual reports of the Ontario Department of Lands and Forests, Fish and Wildlife Division. 


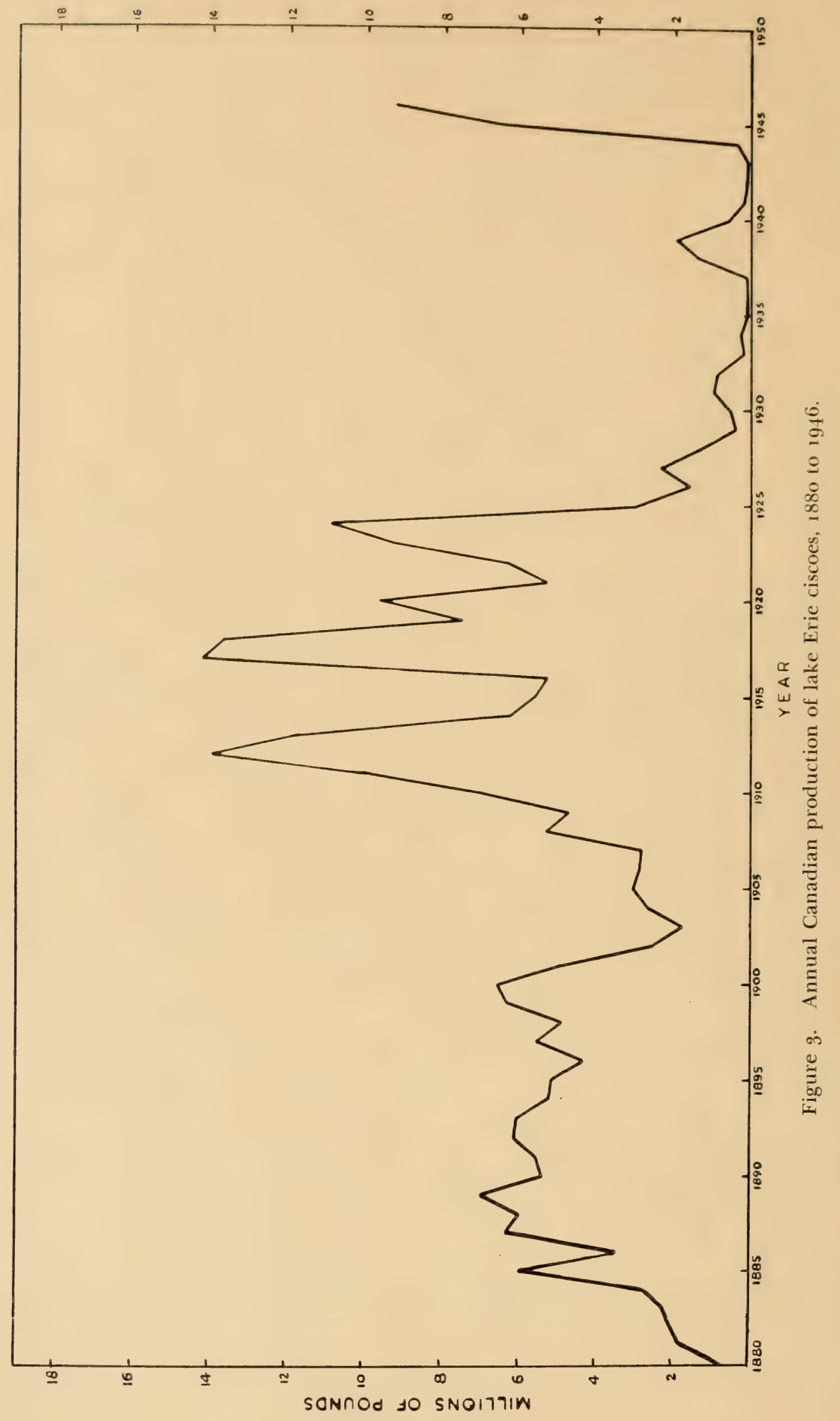




\begin{tabular}{|c|c|c|c|c|c|}
\hline Year & $\begin{array}{l}\text { Catch } \\
\text { in cwt. }\end{array}$ & Year & $\begin{array}{l}\text { Calch } \\
\text { in cwt. }\end{array}$ & Year & $\begin{array}{l}\text { Catch } \\
\text { in cwt. }\end{array}$ \\
\hline 1867 & 20 & 1900 & 65,265 & 1933 & 1,777 \\
\hline 1868 & 16 & 1901 & 48,602 & 1934 & 2,363 \\
\hline 1869 & 302 & 1902 & 25,177 & 1935 & 962 \\
\hline 1870 & 307 & 1903 & 17,281 & 1936 & 788 \\
\hline 1871 & 437 & 1904 & 26,504 & 1937 & 994 \\
\hline 1872 & 958 & 1905 & 30,153 & 1938 & 13,745 \\
\hline 1873 & 1,616 & 1906 & 28,446 & 1939 & 19,734 \\
\hline 1874 & 2,932 & 1907 & 28,214 & 1940 & 5,851 \\
\hline 1875 & 3,232 & 1908 & 53,008 & 1941 & 1,156 \\
\hline 1876 & 6,704 & 1909 & 46,772 & 1942 & 648 \\
\hline 1877 & 5,634 & 1910 & 69,597 & 1943 & 557 \\
\hline 1878 & 6,186 & 1911 & 99,547 & 1944 & 3,356 \\
\hline 1879 & 5,748 & 1912 & 139,654 & 1945 & 64,450 \\
\hline 1880 & 8,820 & 1913 & 116,511 & 1946 & 95,250 \\
\hline 1881 & 18,678 & 1914 & 62,359 & & \\
\hline 1882 & 20,080 & 1915 & 55,947 & & \\
\hline 1883 & 22,550 & 1916 & 52,343 & & \\
\hline 1884 & 27,632 & 1917 & 141,700 & & \\
\hline 1885 & 59,514 & 1918 & 135,320 & & \\
\hline 1886 & 34,217 & 1919 & 74,270 & & \\
\hline 1887 & 63,028 & 1920 & 96,513 & & \\
\hline 1888 & 59,341 & 1921 & 52,254 & & \\
\hline 1889 & 69,025 & 1922 & 63,063 & & \\
\hline 1890 & 53,930 & 1923 & 92,411 & & \\
\hline 1891 & 55,429 & 1924 & 109,079 & & \\
\hline 1892 & 61,263 & 1925 & 28,396 & & \\
\hline 1893 & 60,430 & 1926 & 15,731 & & \\
\hline 1894 & 52,237 & 1927 & 23,087 & & \\
\hline 1895 & 51,397 & 1928 & 12,733 & & \\
\hline 1896 & 42,750 & 1929 & 3,610 & & \\
\hline 1897 & 55,356 & 1930 & 5,066 & & \\
\hline 1898 & 48,603 & 1931 & 9,493 & & \\
\hline 1899 & 62,771 & 1932 & 8,512 & & \\
\hline
\end{tabular}

Table II.* Annual Canadian production in hundreds of pounds of lake Erie ciscoes or lake herring, 1867 to 1946 .

* Compiled from: "Annual landings of fish on the Canadian side of the Great Lakes", by M. Ford, 1943; Annual reports of the Ontario Department of Game and Fisheries; Reports of the Ontario Department of Lands and Forests, Fish and Wildlife Division.

\section{Types of Gear Used in Lake Erie}

Commercial fishing operations in lake Erie are said to have commenced about the year 1815 , when commercial seining began in the vicinity of Maumee Bay, Ohio. Between 1815 and $185^{\circ}$ these operations were carried on mainly by the use of seines in shallow water. About $185^{\circ}$ both pound nets and gill nets appeared in the west and east ends of the lake respectively. Both types of gear were concentrated at first in American waters; for example, the pound net was introduced in the region of Sandusky, Ohio. The newly introduced gear was first employed to capture whitefish but later smaller sized mesh were utilized to take other species. By 1870 commercial fishing in lake Erie was well established. 
1) uring the remaining years of the egth century, gill nets, pound nets, fyke nets, seines and set lines were employed. In addition, American fishermen used the trap net, apparently introduced into Pennsylvania waters about 1885 , but which was illegal in Canadian waters.

Another introduction of considerable importance was that of the steam-powered automatic gill net lifter in 1899-19oo. Before this time gill nets were lifted by hand over a roller. This new machinery enabled the gill net boats to handle a larger number of nets and, from this time onward, the amount of gill net employed in the lake seems to have increased steadily. In the six-year period between 1899 and 1904, the yardage of gill net recorded for Canadian waters of lake Erie was doubled.

In 1905 a modified gill net appeared. This was the bull net*, a gill net some 25 feet deep which was commonly floated off the bottom. Up to the time of the introduction of the bull net most of the herring, in American waters at least, were taken in pound nets. Since 1905, however, gill nets have accounted for more and more of the lake herring captured. The bull net continued to be widely used until the late 1920's and even in 1947 bull nets were used by some American fishermen operating out of New York ports.

For many years past, the standard fishing gear for lake Erie ciscoes has been $27 / 8$ " to $31 / 8^{\prime \prime}$ (stretched mesh) gill net, and even in 1909 Jordan and Evermann stated that at that time the fishermen were satisfied with the $31 / 8$ " gill net for cisco fishing.

Canadian statistics do not cite production by the various types of gear, so that we cannot follow production by gear from year to year, but interviews with the fishermen reveal that no large catches of ciscoes in pound nets have been made on the Canadian side in recent years.

\section{Chief Canadian Gill Netting Localities}

Previous to 1900, gill netting was concentrated from Port Dover eastward, but about 1905 the industry became centred around Port Stanley. About 1925, another shift occurred and Port Dover again became the centre of the gill net industry and has remained so.

* The legal depth of gill nets in the Canadian waters of lake Erie is 36 meshes. Any gill net deeper than 36 meshes is considered to be a bull net. A bull net is illegal gear in Ontario waters only as long as its use is not legalized by any one of the four American states bordering on lake Erie. 


\section{History and Statistics of Production}

An attempt has been made to record available information dealing with the lake Erie cisco fishery commencing in the year 1885 (table II and figure 3). Particular attention has been paid to statements of fishermen and fisheries overseers dealing with apparent abundance, characteristics of fish caught, regions fished, and marketing and weather conditions in cases where these last two factors may affect the total yield. The annual reports of the overseers of the Ontario Department of Game and Fisheries were used extensively but their publication was discontinued after 1914 .

That the lake Erie cisco has long been important among the lake herring fisheries of the Great Lakes is apparent from this statement of Bean's (1903), who, while discussing the lake fisheries of New York State, said: "In 1885 more individuals of this species were taken in lake Erie than in all the other Great Lakes put together, more than 19,000,000 pounds having been caught there, out of a total of less than 26,000,ooo." Bean continues: "I have elsewhere referred to the enormous number taken in 1885 in lake Erie. These are caught chiefly in pound and gill nets. The catch in 1885 amounted to more than onethird of the entire quantity of fish taken in this lake. There is no apparent diminution in the number of these fishes, and their artificial propagation has not been practiced."

In 1891 the ciscoes were said to be numerous and of a large size, especially in the western end of the lake, but heavy gales and storms prevented fishing.

Adverse weather conditions existed in both 1892 and 1893 .

In 1894 poor fishing was said to have prevailed in American waters and, although the Canadian fishermen did not suffer from a scarcity of fish, the production for this year (1894) was below the 1890-1899 average.

During the period 1890-1900, the lake herring was considered to be the chief commercial fish of the lake. The sparning run of lake herring in 1898 was small, the reason advanced being the unusually high autumn temperature. Again late autumn gales impeded fishing operations.

In 1899 herring were unusually plentiful and notice was taken of the large size - i.e., "herring of a greater size than in former years".

While a very successful year was enjoyed by the fishermen in 1900 , the catch would, it was said, have been even greater 
had it not been for two factors; first, herring were late spawning and, secondly, severe storms prevented fishing operations.

In 1gol the Ontario Game and Fisheries Reports specify that the ciscoes were of large size, some weighing as much as two pounds, and commanding a reasonably high price. The fall run at the western end of the lake was said to be "phenomenal". In general, however, the fishing was not considered to be good and concern was expressed in this report that, unless a closed season was established during the spawning run, the herring would not continue to be of importance to lake Erie fishermen. One overseer was quoted as follows: "He feels sure that if steps are not taken at once to protect the herring, in five years, at the present rate of slaughter, the herring fishery in lake Erie will be ruined".

The 1902 reports indicate that herring everywhere were again unusually large, many weighing three pounds and upwards. The overseers, especially for the western end of the lake, claimed that this year marked the beginning of disaster for the herring fishery, and attributed it to the wholesale destruction of the fish during spawning season.

The production of 1903 showed a further decrease. However, severe fall storms were partially responsible for the low catch. Again, opinions expressed by overseers indicated that destruction during the spawning season was, in their minds, the major factor contributing to the decline.

An increase over the previous year's catch took place in 1904 . The substantial increase in yield was attributed to exceptionally fine weather and an absence of gales and storms. Fishing was exceptionally good during September, October and November, and fish continued to be of a large size. Bitter competition between gill and pound net fishermen was commencing, probably as a result of the increasing yardage of gill net being employed.

In the following year, 1905, the fishery commenced late and terminated early because of adverse weather conditions. In general, the overall Canadian catch of ciscoes was greater than in 1904 .

Little change in the fishery was apparent in 19o6. Because of unfavourable weather, fishing over the whole lake was poor during the early part of the season but a successful autumn period was experienced.

Production of all species, but especially that of the lake herring, increased tremendously in 1908 and all available reports 
stated that the hering were more plentiful than in many years. However, as is usual in the case of a market flooded with a perishable commodity, the price dropped to a very low level at times to one-half cent per pound. Most fishermen were said to have actually ended the season in debt because of the extra help required to handle the large numbers of fish. The fall fishing by gill net tugs was especially successful but prices remained low. Of the fish themselves, it is noteworthy that in general they were small, and the use of a larger sized gill net mesh was recommended by some fishermen. It was stated that: "this year has demonstrated beyond doubt that the lake Erie herring has not been depleted". The reports, however, state that this condition existed only on the north shore because of strong prevailing, south and southwest winds, and the fishing on the south shore was said to be not comparable with that on the north shore. However, although this was the opinion of the overseers, the United States statistics show that the American yield was almost exactly twice the Canadian yield. But, it should be realized that the Canadian yield was not indicative of the abundance of fish since many tugs were forced to lay up because of low prices and also many fish were never weighed in, because they spoiled in the nets before removal.

Canadian production in 1909 showed a decrease from 1908 but the price per pound to the fishermen was higher. In the central portion of the north shore ciscoes were said to be more numerous than in the previous year. The fall of the year was marked by storms which seriously hampered fishing.

The catch of ciscoes in 1910 was the highest on record and the fish appear to have been abundant throughout the entire lake. In Elgin County waters, there seems to have been an increase in the amount of jumbo herring taken, one fisherman claiming that $35 \%$ of his catch was composed of jumbo herring. The fishermen at the western end of the lake were said to have suffered because of heavy storms, thus the catch in the late fall was light in that region. From one end of the lake to the other, there appear to have been more ciscoes caught in pound nets; especially was this true of the Port Maitland region.

In 1911 a new catch record was established for the Canadian waters of lake Erie. In the eastern end of the lake, boats out of Port Maitland had large catches. If a fair price had prevailed and the boats continued fishing, it is reported that it would have been the greatest herring catch in the history of the port. Large 
catches of herring were caught in December and enormous quantities were taken during the summer from the same port. Large catches were also taken out of Port Dover. In the Port Stanley-Port Burwell regions, fishing was excellent, especially during November. In the western portion of the lake, small herring were unusually abundant during July and August; in fact, the catch from summer fishing consisted mainly of these small unsaleable fish. The overseer at Blenheim, Kent County, Ontario, reported, ". . . hundreds of tons of them were put back into the water". Similar conditions on a smaller scale were reported for the Nanticoke region. It is noteworthy also that large cisco catches were made by pound nets all along the north shore.

In 1912, saleable lake herring were even more numerous than in 1911; the total yield for the lake had increased steadily since 1909 but 1912 was a peak year. In the eastern region, large catches were taken out of Nanticoke, Port Dover and Port Maitland. The fish taken out of Port Dover were of a larger size than those taken off Port Maitland. The pound nets in this region also had good catches but, in general, the fish taken in the gill nets were of a larger size. Prices were low, however, and large quantities of ciscoes taken in pound nets were allowed to escape uninjured, indicating again that poundage landed is not necessarily in proportion to the number of fish available. In the central region off the north shore, the summer fishing was light because, although ciscoes were numerous, the price was very low so that more effort was made to take whitefish. However, the fall fishing was good and the Port Stanley gill net boats were landing a total of about 200 tons of ciscoes a day. Spring fishing in 1912 in the western portion was light, but large catches were made during June and July off Kent County. It was especially noted that the fish were of a large size, larger than the previous year. Apparently, the fish were not so plentiful off Kent County during August and September - at least the fishermen were unable to take them - but by mid-October, they again became numerous. Fishing appears to have been better off east Kent during the fall than off the central and western portions of the county, but prices were low, falling at times to one cent per pound.

The Canadian catch in 1913, when compared with the previous year, showed a decline of more than two million pounds, yet the total production was still high. In the eastern portion of the lake, off Norfolk and Haldimand Counties, the catch was considered to be good, although lower than in 1912. In the 
central region, ofl Elgin comnty, however, the fishing was exceptionally good, with catches and prices bener than in 1911. In the western region, off Kent County, fishing was late commencing because of a late spring, but herring atches seem to have been confined mainly to the spring and summer lishing. From September to the end of the season, very few herring were caught. It is again noteworthy that the herring in general were much larger this year and there were definite indications that the fish were moving closer to shore and into shallower waters.

In general, the herring were less abundant in 1914 than they had been in 1913 . Haldimand and Norfolk County waters, according to statements, appear to have been exceptions, because herring in these waters were reported by the overseers to be still quite plentiful. That these statements were erroneous and misleading is proven by the fact that the catch for Norfolk County in 1914 was little more than half that of 1913. The statistics show that Elgin and Kent Counties had the highest catches, but it is possible that more gear was employed and, hence, greater effort made to catch ciscoes by these two counties. However, the catch for this year was only a little over half that for 1919 and, of course, the price paid to the fishermen was high.

Unfortunately, the overseers' reports and observations after 1914 were not included in the annual reports of the Ontario Department of Game and Fisheries. The only information available, dealing with the fishery, are statements of actual annual production and papers by various fisheries investigators, but these sources give few details with respect to size of fish, duration of fishing period, weather or other pertinent data.

The annual landings decreased steadily from 1913 to 1916 but in 1917 the all-time Canadian production record of over 14 million tons was established. Canada's maximum yield did not coincide with that of the United States, however, since the highest recorded American yield of over 35 million pounds was attained in 1918. It seems probable that the unusually high production of 1917 and 1918 was stimulated by the World War. Van Oosten (1930) has shown that ciscoes appear to have been generally abundant everywhere in the lake in 1917 and 1918 and further states that ciscoes were especially abundant off Rondeau during the same period.

A more or less steady decline ensued from 1917 and 1918 until 1921. This year, 1921, appears to have been a turning point. The catch then rose steadily until 1924, when another peak yield was attained. 
The year 1925 was an important one in the history of the lake Frie cisco fishery, since it marked the beginning of a disastrous decline which affected the entire lake, in American and Canadian waters alike. The cisco fishery of lake Erie did not, for twenty years, yield an annual production comparable to that of 1924. Van Oosten (1930) has produced evidence which seems to indicate that ciscoes, in 1923 and 1924, congregated abnormally in the deep waters off Long Point. The occurrence of unusual gales and storms during the spring of 1923 was suggested as a possible reason for this abnormal concentration. The catch distribution, by states on the American side, supported the theory since the eastern states of New York and Pennsylvania had unusually high catches, while the catches for Ohio were low. The same condition appeared to prevail on the Canadian side, where the catch from one fishery in the western region of the lake was low during 1923 and 1924, although the total catch was well above average (table III).

\begin{tabular}{cc} 
& $\begin{array}{c}\text { Average number } \\
\text { of }\end{array}$ \\
Year & pounds per net \\
1899 & 99,020 \\
1900 & 56,667 \\
1901 & 50,267 \\
1902 & 7,208 \\
1903 & 8,188 \\
1904 & 6,440 \\
1905 & 3,097 \\
1906 & 8,883 \\
1907 & 9,130 \\
1908 & 17,300 \\
1909 & 13,366 \\
1910 & 22,316 \\
1911 & 48,005 \\
1912 & 55,546 \\
1913 & 30,011 \\
1914 & 7,107 \\
1915 & 2,889 \\
1916 & 6,924 \\
1917 & 41,611 \\
1918 & 21,656 \\
1919 & 5,117 \\
1920 & 5,820 \\
1921 & 753 \\
1922 & 2,196 \\
1923 & 337 \\
1924 & 285 \\
1925 & 81 \\
1926 & 225 \\
1927 & 104 \\
& \\
\hline
\end{tabular}

Table III. Average number of pounds of ciscoes per pound net taken at Rondeau, Ontario, in various years during the period 1899-1927. (From Van Oosten, 1930). 
With regard to the conditions which existed in 1923, 1924 and 1925, Van Oosten (1930) concluded: "To summarize, it may be stated, then, that the disappearance of the Lake Frie ciscoes in 1925 is explained on the basis of a series of unusual circumstances. The ciscoes congregated in a relatively small circumscribed area of the lake in 1923 and 1924; the gill net fishermen followed them and in the firm belief that the supply was extremely abundant, they fished excessively for the ciscoes, in many cases slaughtering them indiscriminately by the tons; tons of ciscoes taken in the bullnets failed to reach the market. The apparent abundance of the ciscoes in 1923-1924 was not real but due to their abnormal distribution; on resumption of normal distribution in 1924 the fishery collapsed for the ranks of adults had been decimated, the breeders had been reduced in numbers, and the progeny, likewise reduced in numbers below the normal, was unable to bring production back to normal. The cisco was commercially exterminated by overfishing."

Referring to the importance of the cisco fishery in lake Erie, Koelz (1926) wrote: "The herring were for many years the mainstay of the fisheries, but with the rise in value of 'rough fish' they no longer occupy so important a position." It seems probable that this refers mainly to the American fishery; also that, with the decrease in numbers of valuable species, less valuable species came into greater demand and hence became more valuable, as noted by Van Oosten (1936 a).

Depletion, which was evident after 1924, was considered to be more serious in American than in Canadian waters and certainly the Canadian decrease in production after 1924 was proportionately less than that in American waters. In 1926 and 1927 the fishery fluctuated at a very low level, the Canadian production for the two-year period being less than four million pounds.

In 1928 a survey, conducted on lake Erie by the Ontario Department of Game and Fisheries, in cooperation with the United States, attempted to discover what factors were responsible for the alarming decrease in fish production. It was concluded that the lake was as capable of supporting as many lake fish as ever and that the depletion must have resulted from overfishing and unwise fishing. The eastern region of the lake was most seriously affected by the decline of the herring fisheries, possibly because more alternative commercial species were available in the central and western regions. 
From 1928 to 1937 the Canadian fishery continued to flucluate at a level below one million pounds, and even the total catch (i.e., American plus Canadian) only exceeded one million pounds on three occasions during this period. Little wonder, then, that Hile and Duden (193.3) considered the cisco fishery of lake Erie to be no longer of commercial importance. Further support for this statement was afforded by Van Oosten (1936 b) who stated: "The once valuable Lake Erie cisco fishery has been completely wiped out commercially, the United States production of ciscoes having dropped from 21 and a quarter million pounds in 1924 to 111,000 pounds in 1934, a decline of 99.5 per cent. in ten years." Until 1938 the story was much the same. Van Oosten (1939) again stated: "In Lake Erie the most valuable species, the cisco, has been wiped out commercially ...."

In 1938 and 1939, however, the fishery experienced a minor increase. The total catch for this two-year period rose to over two million pounds but quickly declined again in 1940. It was generally felt that the rapid reduction in yield after the minor increase in 1938 and 1939 was due to the fishery reducing the stock, and that this reduction of stock could have been avoided had legislative action been taken in time.

This decline continued through 1940, 1941 and 1942, until in 1943 a total of only 81,584 pounds were caught. In Canadian waters, 55,684 pounds were taken, the lowest recorded yield for the lake Erie cisco in these waters since 1871. The American catch was less than $50 \%$ of the Canadian catch for the same year.

Commencing in 1944, however, the catch again increased and, in 1945, Canadian production reached a level comparable with the 1920's. The maximum yield for the recent rise in production was attained in 1946, when over nine million pounds of ciscoes were taken on the Canadian side alone.

The 1947 yield, of $2,484,500$ pounds, showed a distinct decline from that of the previous year.

\section{Cinadian Production by Counties (figure 4)*}

Since 1924 the eastern portion of lake Erie has produced more than $50 \%$ of the ciscoes taken on the Canadian side. Of the six Ontario counties bordering on the lake, the productions of three counties, Haldimand, Norfolk and Elgin, are shown in

\footnotetext{
* See appendix table I.
} 
figure 4. The three remaining counties, Welland, Essex and Kent, having produced only $11.5 \%$ of the total yield over the last ten years (table $\mathrm{I}^{\prime}$ ), were not included in figure 4. Actually, Welland county has not been credited with any cisco production since 1933 .

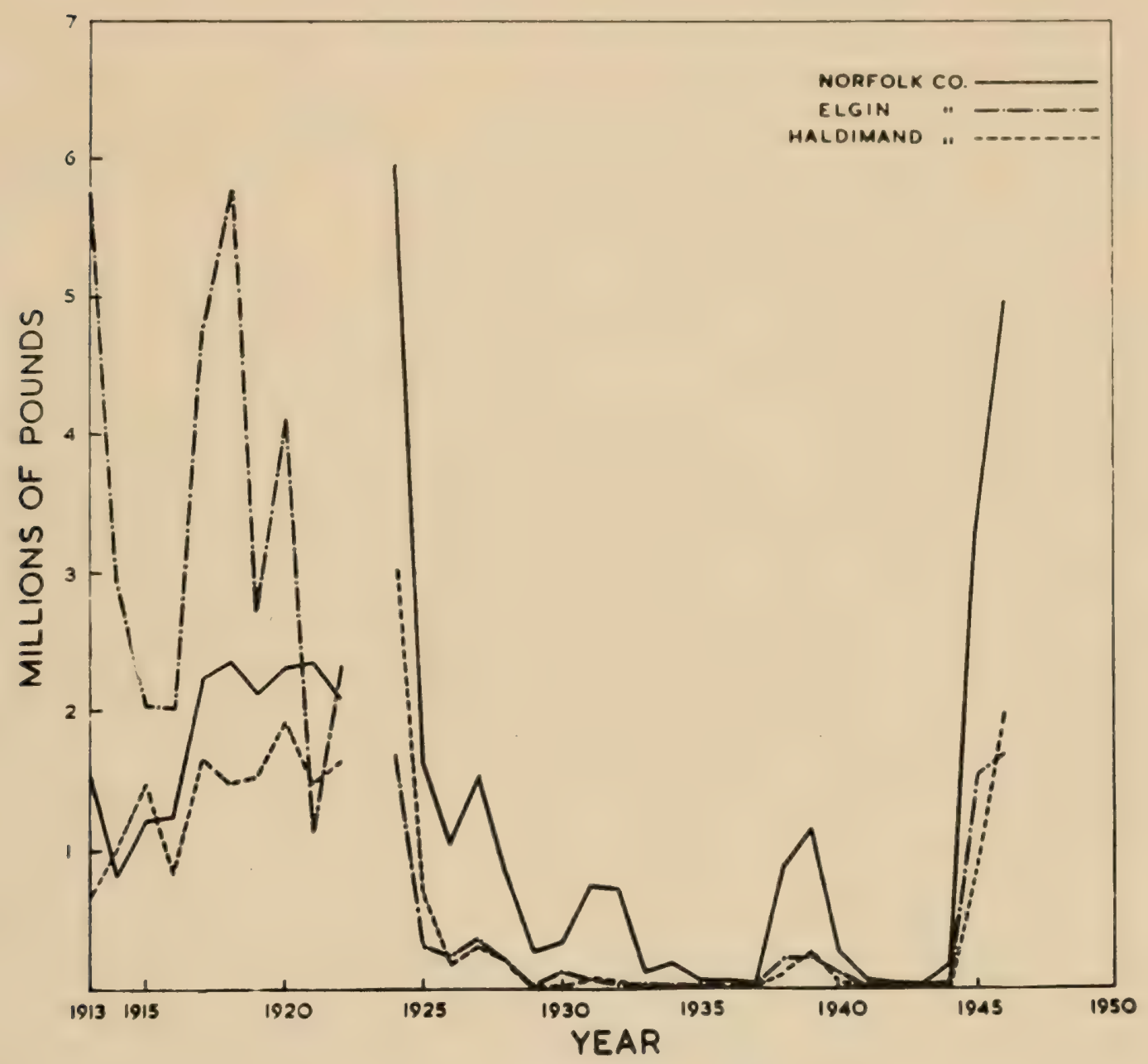

Figure 4. Canadian cisco production of lake Erie by counties.

Considered over a period of ten years, 1937 to 1946 inclusive, the waters off four of these counties, Haldimand, Norfolk, Elgin and Kent, have produced over $99 \%$ of the Canadian yield (table IV). 


$\begin{array}{lc} & \begin{array}{c}\text { Percentage } \\ \text { of } \\ \text { total catch }\end{array} \\ \text { County } & \text { (Canadian waters) } \\ \text { Norfolk } & 53.4 \\ \text { Elgin } & 18.9 \\ \text { Haldimand } & 16.2 \\ \text { Kent } & 10.8 \\ \text { Essex } & 0.7 \\ \text { Welland } & 0.0 \\ & 100 \%\end{array}$

Table IV. Percentage of total lake Erie Canadian cisco production by counties for the period 1937 to 1946 , inclusive.

During the period 1913 to 1946 , the waters off three of these counties, Haldimand, Norfolk and Elgin, yielded $87 \%$ of the total, according to Ontario statistics. Of the four major producers, Norfolk County was by far the largest contributor, having yielded $53.4 \%$ of the total Canadian production over the last ten-year period, with Elgin, Haldimand and Kent Counties following, respectively, for the same period.

Van Oosten (1930) has provided evidence which indicated an abnormal concentration of ciscoes in the eastern portion of lake Erie during 1923 and 1924 and, commencing in 1924*, Norfolk County became the leading producer of ciscoes of all the counties on lake Erie and has maintained its lead to the present day.

Previous to 1924, Elgin County waters were the most productive. Koelz (1926) has stated that until 1925 the gill net industry on the north shore of lake Erie was centred around Port Stanley in Elgin County. Thus, it seems possible that fishing intensity was greatest in Elgin County waters previous to 1925 . However, Norfolk and Haldimand Counties, in general, and Port Dover. (Norfolk County), in particular, became the centre for the gill net industry about 1925 and, about this same time, Norfolk County waters became the leading producer of ciscoes. It is suggested that intensity of fishing alone is not the complete answer. Better fishing or, in other words, a greater concentration of fish in the waters off Norfolk County, would seem to be a more plausible solution.

The greatest amount of summer fishing takes place in the deeper waters which lie off Long Point. This so-called 'deep* The county statistics for 1923 are not available. 
hole' is shared by Haldimand and Norfolk Counties. However, during the spawning run, which takes place in the latter part of November and early December, more fishing takes place off Elgin County than elsewhere in the lake, since the ciscoes seem to concentrate inshore in this region, especially between Port Burwell and Port Stanley. The summer fishing in the western portion of the lake is generally more sporadic than in the east. In certain years the fish may remain throughout the season in Kent and Elgin County waters, wiile in other years they appear to be absent during July and August and are not caught in commercial quantities until September or even October.

\section{Comparison of Canadian and American Production (figure $5^{*}$ )}

Until 1925 the Canadian yield of ciscoes in lake Erie was always lower than that of the United States but, since 1928, Canada has continued to produce more than $50 \%$ of the total yield and has at times produced up to $90 \%$ of that total (table $\mathrm{V})$. It seems probable that the low total yield of the last twenty years may have some bearing on this transfer of greater production from the American to the Canadian side of the lake. However, when the fishery experienced a minor recovery in 1938 and 1939, Canadian waters still produced $62 \%$ and $73 \%$ respectively, of the total yield. Again in 1945, when production reached a level comparable with the early 1920's, the Canadian yield constituted $70 \%$ of the total.

Many reasons could be advanced to explain why Canadian production has been greater than that of the United States, some of which would involve social and economic factors. During the last twenty years the Canadian gill net fishing fleet has increased in size and efficiency. It appears possible that the proportionately greater Canadian yield has resulted because of greater effort on the part of the Canadian gill net fishermen: However, some American waters, especially those off Ohio, which were once famous for cisco fishing, have for many years been considered unsuitable for this species.

* Catch statistics of ciscoes taken in American waters are incomplete prior to 1913. Hence, it is not possible to compare annual landings previous to that year. 


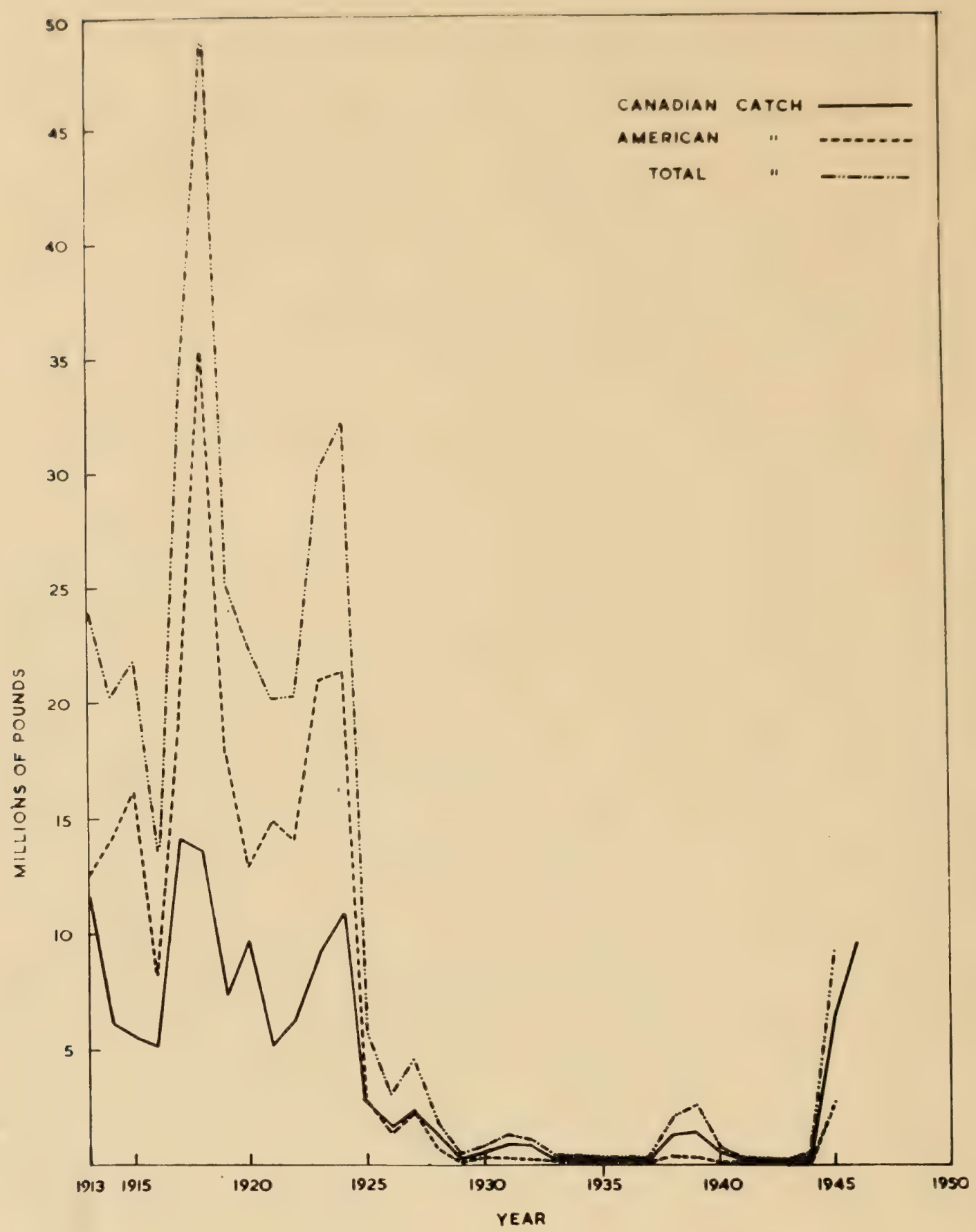

Figure 5. Comparison of Canadian, American and total catch of lake Erie ciscoes for the period 1913 to 1945 . (Canadian production includes 1946). 


\section{Canadian Gisco Production of Lake Erie Compared With That of the Remaining Great Lakes (figure 6).}

A relationship appears to exist between the cisco production of lake Erie and that of the remaining Great Lakes. The Canadian productions of the (rreat Lakes, exclusive of lake Erie, and the production of lake Erie alone, are compared in figure 6. It may be seen that, in general, when lake Erie production is high, the production of the other Great Lakes is low, and vice versa, indicating the existence of a negative correlation.

During the period 1922-1938, as lake Erie production declined from more than ten million pounds annually to less than one million pounds, the production for the remaining Great Lakes rose from less than two million pounds to over six million. Again, in 1938 and 1939 , when a minor recovery was experienced in the lake Erie cisco fishery, the fishery of the remaining Great Lakes declined. The most striking example of

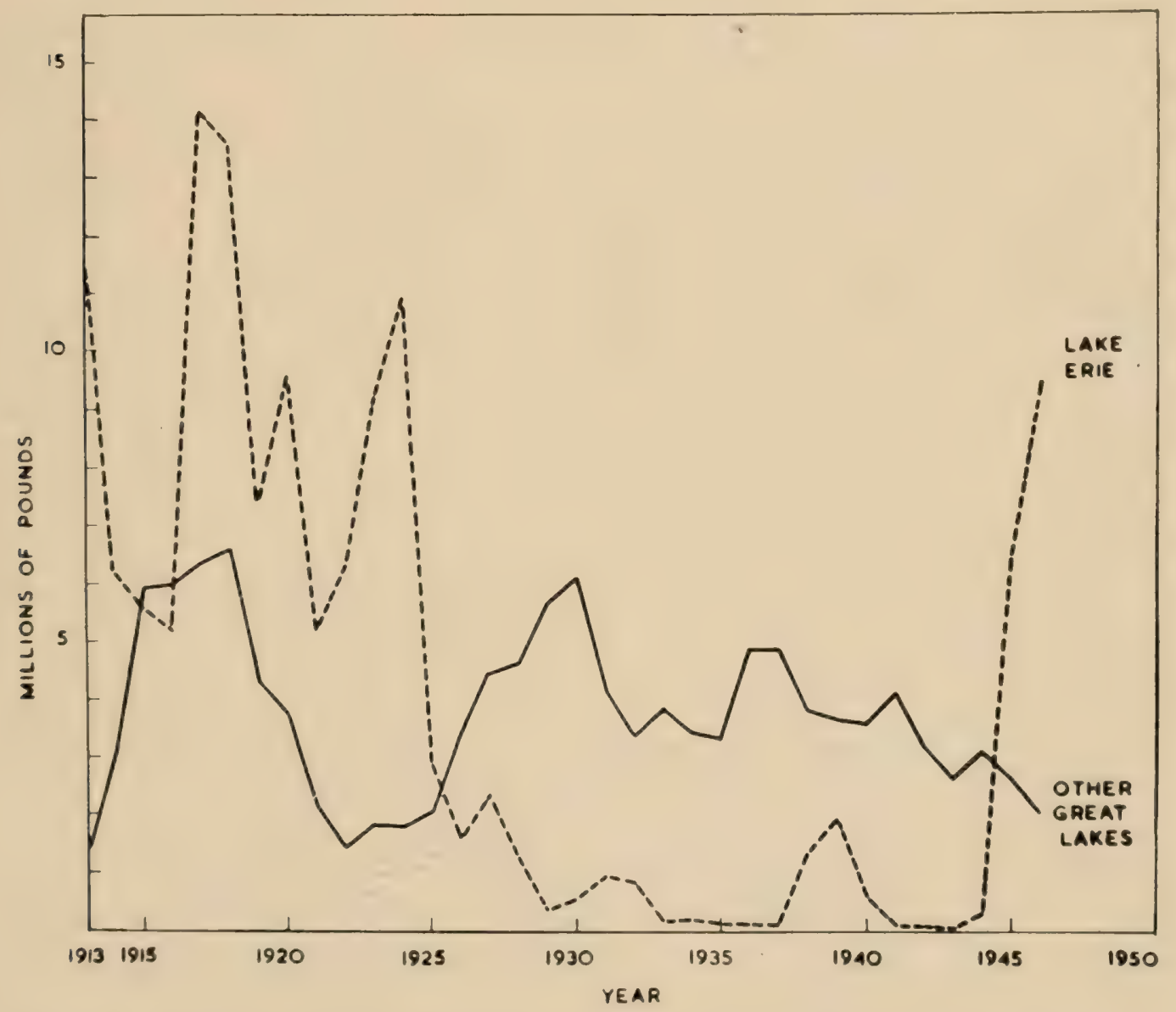

Figure 6. Canadian production of lake herring of lake Erie compared with that of the remaining Great Lakes*.

* See Appendix Table II for statistics. 


\begin{tabular}{|c|c|c|c|c|}
\hline Year & $\begin{array}{l}\text { American } \\
\text { catch } \\
\text { in pounds* }\end{array}$ & $\begin{array}{l}\text { Canadian } \\
\text { calch } \\
\text { in pounds }\end{array}$ & $\begin{array}{c}\text { Canadian } \\
\text { catch } \\
\text { expressed } \\
\text { as a \% } \\
\text { of } \\
\text { total yield }\end{array}$ & $\begin{array}{l}\text { Total calch } \\
\text { in pounds }\end{array}$ \\
\hline 1913 & $12,513,180$ & $11,651,100$ & 48 & $24,164,280$ \\
\hline 1914 & $14,107,982$ & $6,235,900$ & 31 & $20,343,882$ \\
\hline 1915 & $16,236,960$ & $5,594,700$ & 26 & $21,831,660$ \\
\hline 1916 & $8,336,954$ & $5,234,300$ & 39 & $13,571,254$ \\
\hline 1917 & $19,453,146$ & $14,170,000$ & 42 & $33,623,146$ \\
\hline 1918 & $35,290,527$ & $13,532,000$ & 28 & $48,822,527$ \\
\hline 1919 & $17,846,290$ & $7,427,000$ & 29 & $25,273,290$ \\
\hline 1920 & $12,893,192$ & $9,651,300$ & 42 & $22,544,492$ \\
\hline 1921 & $14,964,135$ & $5,225,400$ & 25 & $20,189,535$ \\
\hline 1922 & $14,021,882$ & $6,306,300$ & 31 & $20,328,182$ \\
\hline 1923 & $20,930,284$ & $9,241,100$ & 31 & $30,171,384$ \\
\hline 1924 & $21,292,733$ & $10,907,900$ & 34 & $32,200,633$ \\
\hline 1925 & $2,817,000$ & $2,939,600$ & 51 & $5,756,600$ \\
\hline 1926 & $1,449,305$ & $1,573,100$ & 52 & $3,022,405$ \\
\hline 1927 & $2,350,239$ & $2,308,700$ & 49 & $4,658,939$ \\
\hline 1928 & 618,024 & $1,273,300$ & 66 & $1,891,324$ \\
\hline 1929 & 127,874 & 361,000 & 74 & 488,874 \\
\hline 1930 & 346,016 & 506,600 & 59 & 852,616 \\
\hline 1931 & 345,903 & 949,300 & 73 & $1,295,203$ \\
\hline 1932 & 160,215 & 851,200 & 84 & $1,011,415$ \\
\hline 1933 & 135,500 & 177,700 & 57 & 313,200 \\
\hline 1934 & 110,200 & 236,300 & 68 & 346,500 \\
\hline 1935 & 71,500 & 96,200 & 58 & 167,700 \\
\hline 1936 & 68,000 & 78,800 & 54 & 146,800 \\
\hline 1937 & 64,000 & 99,400 & 61 & 163,400 \\
\hline 1938 & 809,700 & $1,374,500$ & 62 & $2,184,200$ \\
\hline 1939 & 716,700 & $1,973,400$ & 73 & $2,690,100$ \\
\hline 1940 & 62,100 & 585,062 & 90 & 647,162 \\
\hline 1941 & 47,900 & 115,559 & 71 & 163,459 \\
\hline 1942 & 25,200 & 64,789 & 72 & 89,989 \\
\hline 1943 & 25,900 & 55,684 & 68 & 81,584 \\
\hline 1944 & 98,400 & 335,598 & 77 & 433,998 \\
\hline 1945 & $2,764,800$ & $6,444,991$ & 70 & $9,209,791$ \\
\hline 1946 & $\ldots \ldots \ldots \ldots$ & $9,524,975$ & $\ldots$ & \\
\hline
\end{tabular}

Table V. Catch of lake Erie ciscoes, 1913 to 1946.

* Compiled from: International Board of Inquiry for the Great Lakes Fisheries Report and Supplement, 1943; Fisheries Statistics of the United States 1941-1945.

this phenomenon occurred during the recent period of increased production of lake Erie. In 1946, the annual catch from lake Erie was the highest since 1924, while the annual yield for the remaining Great Lakes was the lowest since 1925 .

The causes of this negative correlation between yields do not appear to be the result of interacting biological or physical fac- 
tors within the cisco populations of the Great Iakes, or their enviromment, but instead are economic in origin. An extremely high percentage of the lake Eric cisco production is exported to the United States. Because of the high quality and ready marketability of the lake Erie product, American wholesale dealers prefer to purchase the lake Erie cisco. When the lake Erie cisco is available in quantities large enough to satisfy the market, which is limited, the demand for ciscoes from the remaining Great Lakes declines. Hence, the fishermen of the other Great Lakes do not extensively pursue the lake herring fishery in their respective lakes and, consequently, the production falls. In $194^{6}$ some lake Ontario fishermen simply stated that they did not fish for ciscoes when lake Erie fishermen were catching such large numbers of them. Conversely, when lake Erie ciscoes are scarce, the other Great Lakes fishermen have a ready market for their product, they fish more extensively for lake herring and the production rises, providing the fish are available.

Thus, figure 6 appears to reflect marketing conditions, rather than availability of lake herring in the Great Lakes, other than lake Erie.

\section{AGE COMPOSITION OF SAMPLES}

Probably the most outstanding feature of the cisco population of lake Erie during 1946 to 1948 was the striking predominance of the 1943 year-class. Only the samples taken in the experimental gill nets have been used for eastern region material in table VI, but samples of the commercial catch, taken at different times throughout the course of the study, agree closely with the experimental samples. In 1946, using approximately 1,200 specimens, it was found that the 1943 year-class constituted $97.1 \%$ of all samples. In 1947 the dominance of the 1943 year-class was reduced to $90.4 \%$, mainly by the entry of fish of the 1944 yearclass. These figures pertain to the eastern region of the lake. In the western region in 1947 , the 1943 year-class made up $84 \%$ of the samples, while the 1942 year-class was next in abundance $(12.8 \%)$, a situation slightly different from that obtaining in the eastern portion where the $194^{2}$ year-class constituted only $1.0 \%$ of the samples.

It is thought that dominance of the cisco fishery in lake Erie by one year-class may be the rule rather than the exception. 


\begin{tabular}{|c|c|c|c|c|c|c|c|c|}
\hline \multirow{2}{*}{$\begin{array}{l}\text { Year of } \\
\text { capture }\end{array}$} & & \multicolumn{6}{|c|}{ Year-class } & \multirow[b]{2}{*}{ Totals } \\
\hline & & 1941 & & 1942 & 1943 & 1944 & 1945 & \\
\hline \multicolumn{9}{|c|}{ Eastern region } \\
\hline $\begin{array}{l}1945 \\
1946 \\
1947\end{array}$ & 3 & $(0.2)$ & $\begin{array}{r}5 \\
21 \\
2\end{array}$ & $\begin{array}{r}(20.8) \\
(1.8) \\
(1.0)\end{array}$ & $\begin{array}{r}19(79.2) \\
1159(97.1) \\
167\end{array}$ & $\begin{array}{l}11 \\
15 \quad(8.9)\end{array}$ & $1(0.5)$ & $\begin{array}{r}24(100 \%) \\
1194(100 \%) \\
185(100 \%)\end{array}$ \\
\hline \multicolumn{9}{|c|}{ Western region } \\
\hline 1947 & 1 & (1.1) & 12 & $(12.8)$ & $79(84.0)$ & $2(2.1)$ & & $94(100 \%)$ \\
\hline
\end{tabular}

Table VI. Year-class composition of yearly samples of lake Erie ciscoes taken from two regions of the lake. (Figures in brackets represent percentages.)

\section{YEARS OF PEAK ABUNDANCE}

The rise in cisco production of lake Erie during 1945 and 1946 was due to the presence of a dominant year-class. An analysis of the commercial catches of 1945,1946 and 1947 disclosed that over $90 \%$ of the fish captured belonged to the 1943 year-class. In the fall of 1945 , when the year-class first entered the fishery at age $I$, the fish were relatively small and readily passed through the fishermen's gill nets. By 1946 they were larger and were captured more easily; it seems safe to assume that this year was the peak year for this year-class at age II. By 1947 the ciscoes were quite large, averaging more than one pound in weight, but were not so plentiful (table VII).

Interviews with the commercial fishermen, with respect to the condition of the lake Erie cisco fishery, as it existed during a previous peak of production in the years 1938 to 1941, leads to the belief that the situation during that period was similar to that of the past three years. In $193^{8}$ the fish were small and relatively numerous; by 1939 they had increased in size and, because of the more or less constant size of gill netting used, appeared to have increased in numbers. Production for the period was highest in 1939 but commenced to decline in 1940, in which year the fish were larger than in 1939 and less abundant. It seems possible, therefore, that the increased abundance of $193^{8-}$ 1939 was due, also, to the presence of a dominant year-class, probably that of 1936 .

Table VII, which presents a summary of relative size and abundance of the lake Erie cisco from 1891 to 1947, suggests that previous peaks of abundance probably also owed their existence to dominant year-classes. During the period 1907 to 1926 the occurrence of dominant year-classes during years of 
peak abundance seems very probable. The reserve stock was possibly higher than in recent years, perhaps because fishing intensity was not as great. The periods, 1911 to 19) 19, 1917 and 1918 , might serve as examples. The sizes and abundance of ciscoes during the years 1911 to 1913 seems to follow a trend similar to that of $1945^{-1947 . ~ F o r ~ t h e ~ y e a r s ~} 1917$ to 1918 , while notes and

\begin{tabular}{|c|c|c|}
\hline Year & Size & Abundance \\
\hline 1891 & large & numerous \\
\hline 1894 & $--\cdots$ & scarce \\
\hline 1899 & large & numerous \\
\hline 1901 & $\begin{array}{l}\text { large, some weighing } \\
\text { two pounds }\end{array}$ & scarce \\
\hline 1902 & $\begin{array}{l}\text { unusually large, some } \\
\text { weighing three pounds } \\
\text { and upwards }\end{array}$ & very scarce \\
\hline 1903 & - - - & scarcer than in 1902 \\
\hline $\begin{array}{l}1904 \\
1908\end{array}$ & $\begin{array}{l}\text { large } \\
\text { small }\end{array}$ & abundant \\
\hline 1909 & $-\cdots$ & less abundant \\
\hline 1910 & $\begin{array}{l}\text { high proportion of } \\
\text { caich composed of } \\
\text { large fish }\end{array}$ & $\ldots$ \\
\hline 1911 & very small & tremendously abundant \\
\hline 1912 & larger than in 1911 & abundant \\
\hline 1913 & larger than in 1912 & less abundant than in 1912 \\
\hline 1914 & $--\overline{11}$ & less abundant than in 1913 \\
\hline 1938 & small & abundant \\
\hline 1939 & larger & abundant \\
\hline 1940 & larger than in 1939 & scarce \\
\hline 1945 & very small & abundant \\
\hline 1946 & larger than in 1945 & abundant \\
\hline 1947 & larger than in 1946 & becoming scarce \\
\hline
\end{tabular}

Table VII. Summary of statements and observations regarding size of individuals and relative abundance of ciscoes in lake Erie during the period 1891-1947.

observations as to sizes and abundance are not available, the production curve (figure 3) is certainly similar to those production curves of the two periods mentioned. However, it is possible that the production was simply a result of increased effort due to the greater demand for food resulting from World War I. This may still have been the case in 1920. For the years 1923 and 1924 Van Oosten (1930) has produced evidence that the apparent increase in abundance was due to abnormal aggregation of the ciscoes, due to temperature considerations, but a dominant year-class may also have been present.

In view of the recent increase in abundance during 1945 and 1946 and decline in numbers during 1947 , due to the dependence of the fishery on one year-class, the theory of the past existence of dominant year-classes of ciscoes in lake Frie assumes 
more importance. The cisco fishery has experienced such violent fluctuations that the need for a better understanding of the fishery is urgent. Overfishing alone does not appear to be the complete answer to the problem.

\section{IMPORTANCE OF SIZE OF SPAWNING STOCK}

It has been noted previously that the Canadian catches of over $6,000,000$ pounds in 1945, and 9,000,000 pounds in 1946, resulted from one year-class, that of 1943, passing through the fishery. Yet, the commercial catch in 1943 was the lowest recorded since 1871 . Thus, at least $15,000,000$ pounds of ciscoes were produced by a population which was apparently so low in numbers that only 55,700 pounds were taken. To assume that a larger population than indicated by the commercial catch existed in 1943, and was undetected by the fishermen, is hardly feasible. Lake Erie is very extensively fished by experienced men and efficient gear and, if a larger population had been present, it would, undoubtedly, have been discovered. It must, therefore, be concluded that only a relatively small population of ciscoes was present on the spawning grounds. Due to one or more factors favourable to the survival and growth of the eggs and fry, the resulting year-class was almost unbelievably successful. It is, however, possible that if the spawning stock had been larger the resulting yield might also have been larger.

Therefore, it does not appear that a large spawning stock is essential for the successful maintenance of the lake Erie cisco fishery.

\section{FACTORS RESPONSIBLE FOR DOMINANT YEAR-CLASSES}

A dominant year-class obviously results from the hatching and/or survival of an unusually large number of individuals. It is vital to determine whether the most important factor is unusually successful hatching or whether sufficient eggs always hatch to give a large year-class if the fry survive. In other words, is hatching, or survival after hatching, the more important? Investigators of marine fisheries are also concerned with this question. E. S. Russell (1942) has stated: “ . . . there is no necessary connection between the number of eggs produced in a particular spawning season and the amount of fry which survives; on the contrary, poor spawning years have often been 
good brood years. The fate of the year-class is settled not by the number of eggs produced, which is enormous, but by the relatively small number of fry that survive, and the critical period of great mortality falls in the first few days or weeks after the eggs are spawned." Whether this critical period is of short duration, say a few days or weeks as stated by Russell, or whether it is of longer duration extending possibly to months, is a debatable point on which little information is available.

Among marine fishes, the herring (Clupea harengus) and the haddock (Melanogrammus eaglefinus) show marked fluctuations. One of the most striking cases of dominance by a year-class was that of the Norwegian herring (Clupea harengus) studied by Hjort (1926). Hjort's studies revealed that an enormously successful production of fry in 1904 resulted in a year-class (that of 1904) which dominated the commercial fishery from 1908 through 1918 , a period of eleven years.

Few freshwater fishes have exhibited a dominance as marked as that of the lake Erie cisco. The commercial catch was so exceptionally small, 55,000 pounds, the year the successful yearclass was spawned (1943) that it seems logical to conclude that the number of eggs spawned was also small. It is thought that the present study indicates clearly the major importance of the factors influencing hatching and/or survival of lake Erie ciscoes rather than numbers spawned. It is, therefore, pertinent to consider the importance of the factors influencing hatching and/or survival.

\section{Factors Influencing Hatching and Survival}

Two categories of factors affecting hatching appear to exist, those within the body of water such as food, predators and unbalanced sex ratios, and those arising from meteorological conditions such as winds, rainfall and temperature. The latter may so affect the environment that excessive silting, mechanical damage due to wave action, unfavourable temperatures and chemical composition of the water may be so combined that the resulting hatch is either large or small. Once hatched, survival would appear to depend mainly on presence or absence of food, predators and disease. Errington (1946) has concluded that predation may have a more significant effect on fish populations than on many other animals.

It is the belief of the author that in the case of the lake Erie cisco, the success of the 1943 year-class was due to un- 
usually successful survival alter hatching. As previously menlioned, available evidence indicates that the number of eggs laid was small. Secondly, at least four species other than the cisco have exhibited, or are exhibiting, dominant year-classes which date back to the early spring of 1944, the time the eggs of the 1943 cisco spawning would be hatching. The 1943 year-class of ciscoes and whitefish, both of which are fall spawning species, whose eggs hatch in the late winter of the following year, and the 1944 year-classes of perch, blue pike-perch and smelt, all of which are spring spawning fishes, have exhibited dominance. It seems reasonable to assume that, if one species is unusually successful in a certain year, others might also exhibit the same tendency. This, of course, implies that an abundance of planktonic food of the necessary size and type must be available at the critical times and in the critical places.

The eggs of all five species do not hatch at the same time, nor are the eggs laid on the same spawning grounds. Each species has its own spawning requirements. The fact remains that these particular year-classes of all species mentioned have been dominant and age composition analyses have revealed that in every case the survival of the hatch of the late winter and spring of 1944 was unusually successful.

The conclusion is, then, that favourable conditions for survival must have existed over a fairly prolonged period.

\section{Plankton Abundance}

Unfortunately, the investigations carried out in the eastern waters of lake Erie, and in the region of Long Point in particular, have not included plankton studies. Hence, no information dealing with plankton abundance is available for this region of the lake and it is impossible to determine the state of plankton abundance during the critical year. However, studies by Dr. D. C. Chandler, of the Franz Theodore Stone Laboratory at Put-in-Bay, Ohio, revealed that plankton was unusually abundant in the western region of lake Erie during the early part of 1944. It is possible that the same situation existed in the eastern region, but in any case it is not known if plankton abundance has ever been a limiting factor for the survival of lake Erie ciscoes.

\section{Predation}

Recent work suggests that the effect of predators on fish populations is probably of more significance than has been pre- 
viously thought. Errington (1946) has concluded that predation may be of more importance in fish populations than in the case of many other animals. Experiments by Foerster and Ricker (1941) have indicated that destruction of fish predators significantly increased the survival of young sockeye.

As in the case of plankton abundance, no information is available concerning the food of predator species during the critical year, 1944, but it is assumed that, in view of the high survival, the effect of predation was probably not great.

Disease

The influence of disease on populations of freshwater fishes is little understood. Among populations of birds and animals there is evidence to indicate that disease exerts a maximum effect when population density is at a peak. In general, it is a factor which may accelerate the rate of decline or die-off of a population, but as yet there appears to be no data to indicate its importance among fishes.

\section{Fecundity of Lake Erie Ciscoes}

Fluctuations of populations are usually more pronounced among animals having a high biotic potential. Dymond (1947) has stated: "The size of a population of any species is the result of the inter-action of two sets of forces often designated as biotic potential and environmental resistance."

While it has been concluded that in the case of the lake Erie cisco the number of eggs laid in 1943 was probably not unusually large, that does not preclude the possibility that had more eggs been laid the subsequent production of ciscoes might have been even greater. In any case, it was felt that a preliminary study of the fecundity of the species would provide valuable data.

Previous fecundity studies of ciscoes have been few. Stone (1937) investigated the fecundity of Leucichthys artedi in lake Ontario, while Brown and Moffet (1942) have recorded observations on a few specimens from a small lake in Michigan.

The usual method of estimating the number of eggs by weighing and counting small samples was employed. Brown and Moffet (1942) did partial and total counts on three specimens and found that five gram samples (error 6.7 per cent.) were almost as accurate as 70 gram samples (error 5.4 per cent.). In view of these data, five gram samples were used. The samples were selected at random after breaking up the ovary and mixing the eggs. 
The $194^{6}$ counts were made on fish of the 1943 year-class at age II, ranging in size from 10.5 ounces to 24.0 ounces (tab)le IX). Since the counts were made in August and September, all ovaries were "green", or unripe. In 1947, fish of the 1949 and 1944 year-classes were employed at ages II and III, ranging in size from 15.5 ounces to 35.5 ounces (table IX). All counts of age III ciscoes were made on ripe specimens. Because of ripeness, the eggs were readily exuded. It is felt that, due to the ripeness, some eggs were probably lost as a result of netting and subsequent handling, thus accounting for the relatively low values obtained from the 1947 samples. On the other hand, since ten of the twelve age II specimens were taken during September, it is possible that the count was high because the eggs were not fully mature and, consequently, the samples used may have contained eggs which would not have developed.

Stone (1937), in a study of the fecundity of Leucichthys artedi of lake Ontario from Irondequoit Bay, New York, concluded: " . . . the heavier and longer fish of an age group tend to be the most productive although considerable variation occurs." Stone's data, on which this conclusion was based, is presented in table VIII.

\begin{tabular}{ccccc}
\hline Age & $\begin{array}{c}\text { Number } \\
\text { of } \\
\text { group }\end{array}$ & $\begin{array}{c}\text { Standard } \\
\text { length } \\
(\text { mm.) }\end{array}$ & $\begin{array}{c}\text { Weight } \\
\text { (gms. })\end{array}$ & $\begin{array}{c}\text { Average } \\
\text { number } \\
\text { of eggs } \\
\text { perfemale }\end{array}$ \\
II & 8 & 255 & 338.3 & 13,723 \\
III & 78 & 282 & 456.4 & 21,824 \\
V & 2 & 317 & 580.8 & 27,846 \\
VI & 9 & 324 & 733.6 & 38,606 \\
VII & 4 & 329 & 781.7 & 35,928 \\
VIII & 3 & 356 & 938.8 & 48,999 \\
\hline
\end{tabular}

Table VIII. Average fecundity, length and weight of 104 Irondequoit Bay ciscoes (from Stone, 1937).

This study of lake Ontario ciscoes appears to be the most intensive study available. Actual counts were made on nine specimens, and estimated counts, using a volumetric method, on 104 specimens. Brown and Moffet, on the other hand, using only nine females, concluded that no correlation existed between the size or age of fish and the number of eggs produced, although they realized that their sample was not large enough to allow 
the drawing of reliable conclusions. They obtained an average count of 30,328 eggs, using lish varying in age from $V^{\prime}$ to IX years.

The material used in the present study consisted of 16 specimens of the 1943 year-class and two of the 1944 year-class.

The results of the egg counts of lake Erie ciscoes are shown in table IX.

\begin{tabular}{|c|c|c|c|c|c|c|}
\hline & & Age II & & & Age III & \\
\hline $\begin{array}{l}\text { Year- } \\
\text { class }\end{array}$ & $\begin{array}{l}\text { Standard } \\
\text { length } \\
(\mathrm{mm} .)\end{array}$ & $\begin{array}{l}\text { Weight } \\
\text { (ounces) }\end{array}$ & $\begin{array}{l}\text { Calculated } \\
\text { number } \\
\text { of eggs } \\
\text { per } \\
\text { female }\end{array}$ & $\begin{array}{l}\text { Standard } \\
\text { length } \\
(\mathrm{mm} .)\end{array}$ & $\begin{array}{l}\text { Weight } \\
\text { (ounces) }\end{array}$ & $\begin{array}{c}\text { Calculated } \\
\text { number } \\
\text { of eggs } \\
\text { per } \\
\text { female }\end{array}$ \\
\hline $\begin{array}{l}1943 \\
1943 \\
1943 \\
1943 \\
1943 \\
1943 \\
1943 \\
1943 \\
1943 \\
1943 \\
1944 \\
1944 \\
\end{array}$ & $\begin{array}{l}249 \\
278 \\
272 \\
297 \\
299 \\
282 \\
291 \\
309 \\
270 \\
290 \\
297 \\
307 \\
\end{array}$ & $\begin{array}{l}10.5 \\
15.5 \\
19.0 \\
21.0 \\
20.0 \\
19.5 \\
19.0 \\
24.0 \\
15.0 \\
20.5 \\
20.0 \\
23.0 \\
\end{array}$ & $\begin{array}{l}16,000 \\
25,800 \\
26,700 \\
29,500 \\
29,800 \\
30,400 \\
31,300 \\
33,600 \\
35,400 \\
42,500 \\
21,700 \\
28,200 \\
\end{array}$ & $\begin{array}{l}311 \\
294 \\
355 \\
345 \\
339 \\
318\end{array}$ & $\begin{array}{l}18.5 \\
15.5 \\
33.5 \\
31.0 \\
35.5 \\
25.0\end{array}$ & $\begin{array}{l}14,200 \\
15,800 \\
18,900 \\
20,200 \\
30,400 \\
38,600\end{array}$ \\
\hline Averages & 287 & 18.9 & 29,225 & 327 & 26.5 & 23,017 \\
\hline
\end{tabular}

Table IX. Egg counts for lake Erie ciscoes at ages II and III.

The average count for 12 females taken at age II was 29,225 eggs, while six females taken the following year at age III averaged only 23,017 eggs. The average count at age II of 29,225 eggs compares favourably with the overall average of Brown and Moffet (1942) of 30,328 eggs for all ages, but is much higher than the average of 13,723 eggs for age II recorded by Stone (1937). At age III the average count for the present study was 23,017 eggs, which is slightly higher than the 21,824 eggs determined by Stone for the same age group. As previously mentioned, however, it was felt that the age III egg counts were low since the eggs were being exuded freely due to the ripeness of the fish. Also, at comparable ages the lake Erie ciscoes are longer and heavier than those of lake Ontario studied by Stone.

The egg counts presented in table IX appear to exhibit a tendency to increase in number with increase in length and weight of the female. This tendency is in agreement with the conclusion recorded by Stone for lake Ontario ciscoes. 
Therefore, it is concluded on the basis of the present study that, at comparable ages, lake Erie ciscoes have a higher egg count than those of lake Ontario as recorded by Stone, and, further, that the apparently higher fecundity of lake Erie ciscoes is correlated with the larger size of lake Erie ciscoes as compared with those of lake Ontario examined by Stone.

\section{SUMMARY}

For at least 50 years the lake Erie cisco fishery has fluctuated violently. From 1910 to 1925 these fluctuations were especially marked. During the period 1926-1944 the fishery was virtually extinct, but in 1945 and 1946 the cisco reappeared in numbers comparable to the best years of the fishery.

A history of the fishery is presented as a basis for an understanding of the recent abundance.

The eastern portion of the lake, especially that off Norfolk County, is the heaviest producer of ciscoes.

During the years of low production, 1926-1944, Canadian waters have been more productive than American waters. They maintained this lead even during the recent years of abundance.

There exists an inverse relationship between the cisco catch of lake Erie and that of the remaining Great Lakes. When the lake Erie catch is high, that of the remaining Great Lakes is low and vice versa. The lake Erie cisco is preferred by the market. When it is available in quantity, cisco fishing in the other Great Lakes is not profitable and, hence, the catch is low. Conversely, low catches in lake Erie result in a more open market and cisco fishing is pursued more vigourously on the other Great Lakes.

Over $95 \%$ of the commercial catch in 1946 , the year of greatest recent abundance, consisted of fish of the 1943 year-class.

The history of past populations supports the theory that previous periods of abundance resulted from the occurrence of dominant year-classes similar to that of 1943 .

It has been concluded that the size of the spawning stock in 1943 was unusually small, since the commercial catch in 1943 was the lowest in over sixty years.

There are three important phases to be passed if a successful year-class is to be produced, i.e., number of eggs laid (or size of spawning stock), number of eggs hatched, and mortality rate of the young fish until they enter the commercial fishery. Survival of young fish depends upon the presence or absence of 
food, predators and disease. In the present study montality rate appears to have been the most important phase.

Inder lavourable conditions, therefore, an unusually small spawning population can produce a large year-class.

\section{REFERENCES}

ANNuAl Repokts of the Ontario Department of Game and Fisheries, $1867-1946$.

AxNUAL RFPORTS of the Ontario Department of Lands and Forests, 1947-1948.

BeAN, T. H., 1903: Catalogue of the fishes of New York, N.Y. State Museum Bull. 60: $1-784$.

Brown, C. J. D. and J. W. MoffetT, 1942: Observations on the number of eggs and feeding habits of the cisco (Leucichthys artedi) in Swains Lake, Jackson County, Michigan. Copeia, 3: 149-152.

Burkenroad, M. D., 1946: Fluctuations in abundance of marine animals. Science, No. 2684, 103: $684-686$.

Dymovi, J. R., 1947: Fluctuations in animal populations with special reference to those of Canada. Trans. Roy. Soc. Can., 41: sec. V: 1-34.

Eltov, C., 1924: Periodic fluctuations in the numbers of animals: their causes and effects. Brit. J. Expt'l Biol., 2: 119-163.

1930: Animal ecology and evolution. Oxford.

1942: Voles, mice and lemmings: problems in population dynamics Oxford.

Errixgron, P. L., 1946: Predation and vertebrate populations. Quart. Rev. Biol., 21: $144^{-177 ;} 221-245$.

Fisheries Statistics of the United States. Fish and Wildlife Service, United States Department of the Interior, 1941-1945.

Foerster, R. E. and W. E. Ricker, 1941: The effect of reduction of predaceous fish on survival of young sockeye salmon at Cultus Lake. J. Fish. Res. Board of Canada, 5: 315-336.

FORD, MARJORY A., 1943: Annual landings of fish on the Canadian side of the Great Lakes from 1867 to 1939. Bd. of Inquiry for Great Lakes Fisheries. Ottawa.

Hrle, R. and W. R. Duden, 1933: Methods for the investigation of the statistics of the commercial fisheries of the Great Lakes. Trans. Amer. Fish. Soc., 63: $292-305$.

HJORT, J., 1926: Fluctuations in the year-classes of important food fishes. J. Cons. Perm. Int. pour l'Exp. de la Mer, 1: 5-38.

International BoArd of Inguiry for the Great Lakes Fisheries. Report and Supplement. U. S. Govt. Printing Office, 1943.

Jordan, D. S. and B. W. EvErmanN, 1911: A review of the Salmonoid fishes of the Great Lakes, with notes on the whitefishes of other regions. Bull. U.S. Bur. Fish., 29: 1-41.

Koelz, Walter N., 1926: Fishing industry of the Great Lakes. U.S. Dept. Comm. Bur. Fish. Doc., 1001: 553-617.

P'EARL, R., 1937: On biological principles affecting populations: human and other. Amer. Nat., 71: 50-68.

Russell, E. S., 1942: The overfishing problem. Cambridge University Press.

Stevenson, J. C., 1944: The smelt situation in the upper Great Lakes, Ontario, May, 1943. Can. Field-Nat., 56: 411-419.

Stone, U. B., 1937: Growth, habits and fecundity of the ciscoes of Irondequoit Bay, New York. Trans. Amer. Fish. Soc., 67: 234-245.

VAN Oosten, JoHn, 1930: The disappearance of the lake Erie cisco - a preliminary report. Trans. Amer. Fish. Soc, 60: 204-214.

-1936 a: Fishing industry of the Great Lakes. U.S. Dept. Comm. Bur. Fish. Memorandums $1-63$.

1936 b: The Great Lakes fisheries: their proper management for sustained yields. Trans. Amer. Fish. Soc., 66: 131-138.

1939: Save the Great Lakes fisheries. Outdoor America. Jan. 


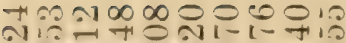 \\ $0 \mathrm{j}+\mathrm{i}-\infty \infty 0 \infty \mathrm{i}-\mathrm{-1}$ \\ จंक- \\ 개용}

î

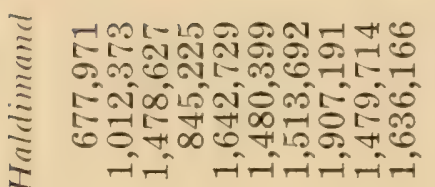

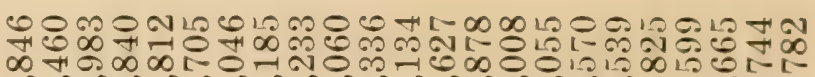
A 0000

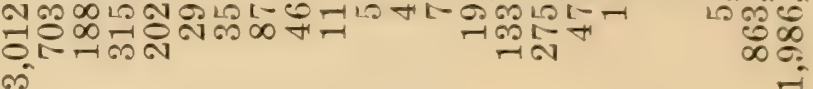

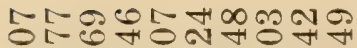
* R

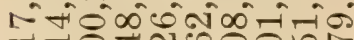

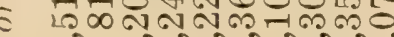
5.그.

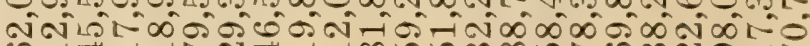

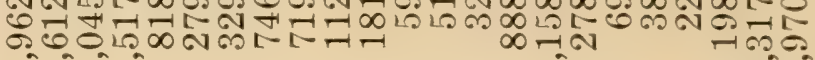

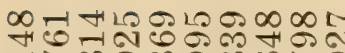
₹

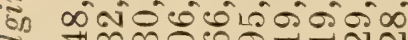
ज คी

O.

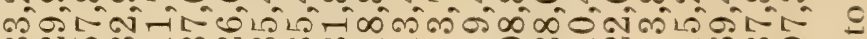
ชูกตั (ni-i

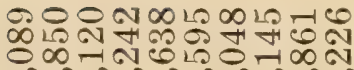

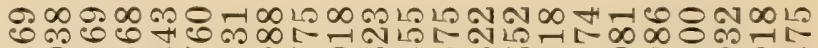
\% O H. ง ¿ ain सion

2L 2000 N $\infty 10,0000$ H H 10 ง $\infty 00-100$ mis

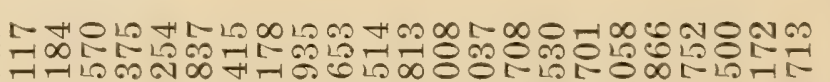

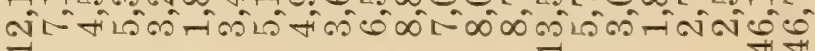




\begin{tabular}{|c|c|c|c|}
\hline Year & $\begin{array}{l}\text { Lake Erie } \\
\text { Canadian } \\
\text { catch } \\
\text { in pounds }\end{array}$ & $\begin{array}{c}\text { Tolal } \\
\text { Canadian } \\
\text { production } \\
\text { for } \\
\text { Creat Lakes } \\
\text { in pounds }\end{array}$ & $\begin{array}{l}\text { Canadian } \\
\text { production } \\
\text { for } \\
\text { cireat Lakes } \\
\text { minus } \\
\text { I.ake Erie } \\
\text { production } \\
\text { in pounds }\end{array}$ \\
\hline 1913 & $11,651,100$ & $12,973,517$ & $1,322,417$ \\
\hline 1914 & $6,235,900$ & $9,324,456$ & $3,088,556$ \\
\hline 1915 & $5,594,700$ & $11,479,570$ & $5,884,870$ \\
\hline 1916 & $5,234,300$ & $11,213,504$ & $5,979,204$ \\
\hline 1917 & $14,170,000$ & $20,511,949$ & $6,341,949$ \\
\hline 1918 & $13,532,000$ & $20,057,525$ & $6,525,525$ \\
\hline 1919 & $7,427,000$ & $11,700,532$ & $4,273,532$ \\
\hline 1920 & $9,651,300$ & $13,407,423$ & $3,756,123$ \\
\hline 1921 & $5,225,400$ & $7,396,390$ & $2,170,990$ \\
\hline 1922 & $6,306,300$ & $7,738,134$ & $1,431,834$ \\
\hline 1923 & $9,241,100$ & $11,032,331$ & $1,791,231$ \\
\hline 1924 & $10,907,900$ & $12,671,400$ & $1,763,500$ \\
\hline 1925 & $2,939,600$ & $4,952,631$ & $2,013,031$ \\
\hline 1926 & $1,573,100$ & $5,012,754$ & $3,439,654$ \\
\hline 1927 & $2,308,700$ & $6,766,549$ & $4,457,849$ \\
\hline 1928 & $1,273,300$ & $5,935,275$ & $4,661,975$ \\
\hline 1929 & 361,000 & $6,043,855$ & $5,682,855$ \\
\hline 1930 & 506,600 & $6,599,162$ & $6,092,562$ \\
\hline 1931 & 949,300 & $5,107,667$ & $4,158,367$ \\
\hline 1932 & 851,200 & $4,252,961$ & $3,401,761$ \\
\hline 1933 & 177,700 & $4,032,699$ & $3,854,999$ \\
\hline 1934 & 236,300 & $3,724,934$ & $3,488,634$ \\
\hline 1935 & 96,200 & $3,442,025$ & $3,345,825$ \\
\hline 1936 & 78,800 & $4,966,981$ & $4,888,181$ \\
\hline 1937 & 99,400 & $4,984,916$ & $4,885,516$ \\
\hline 1938 & $1,374,500$ & $5,210,189$ & $3,835,689$ \\
\hline 1939 & $1,973,400$ & $5,670,631$ & $3,697,231$ \\
\hline 1940 & 585,062 & $4,218,100$ & $3,633,038$ \\
\hline 1941 & 115,559 & $4,253,983$ & $4,138,424$ \\
\hline 1942 & 64,789 & $3,284,678$ & $3,219,889$ \\
\hline 1943 & 55,684 & $2,745,284$ & $2,689,600$ \\
\hline 1944 & 335,598 & $3,460,034$ & $3,124,436$ \\
\hline 1945 & $6,444,991$ & $9,121,670$ & $2,676,679$ \\
\hline 1946 & $9,524,975$ & $11,574,377$ & $2,049,402$ \\
\hline
\end{tabular}

Table II. Canadian production of ciscoes for lake Erie, for the Great Lakes and for the Great Lakes other than lake Erie. 



3048

9083

8 





13)

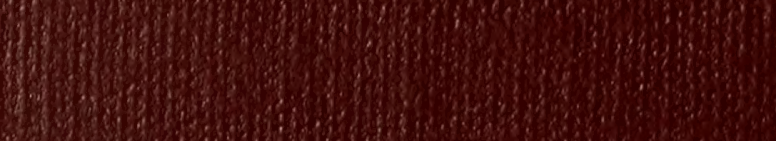

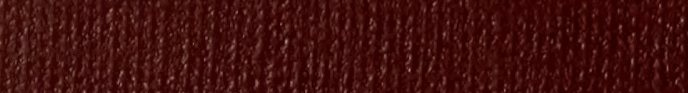

3.6.

3.13)

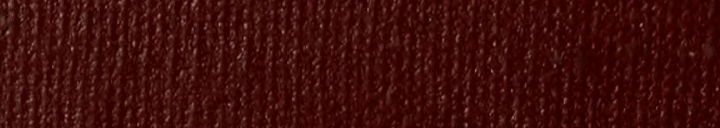

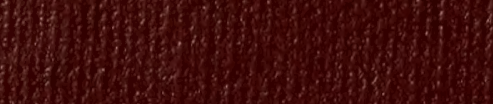
(3)

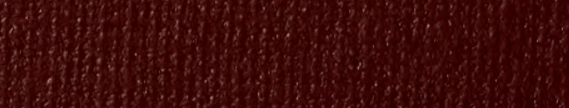

